\title{
Soil pH and the Activity of a Pelletized Nematophagous Fungus
}

\author{
B. A. Jaffee and R. J. Zasoski
}

First author: Department of Nematology, University of California, 1 Shield Ave., Davis 95616; and second author: Department of Land, Air, and Water Resources, University of California, 1 Shield Ave., Davis 95616.

Accepted for publication 27 November 2000.

ABSTRACT

\begin{abstract}
Jaffee, B. A., and Zasoski, R. A. 2001. Soil pH and the activity of a pelletized nematophagous fungus. Phytopathology 91:324-330.

When formulated as assimilative hyphae in alginate pellets, the nematophagous fungus Hirsutella rhossiliensis was more active (i.e., parasitized more assay nematodes) in an acidic vineyard soil than in a neutral vineyard soil. To determine whether soil $\mathrm{pH}$ explained the difference, fungus activity was measured in soil from the neutral site that had been acidified (by adding sulfuric acid) and in soil from the acidic site that had been neutralized (by adding calcium hydroxide). As hypothesized, the activity of pelletized Hirsutella rhossiliensis was negatively correlated with soil $\mathrm{pH}$. Maximum activity occurred at $\mathrm{pH}_{\text {calcium chloride }} 4.5$, and activity gradually declined to near zero as the $\mathrm{pH}$ increased to 6.5
\end{abstract}

and rapidly declined to near zero as the $\mathrm{pH}$ dropped below 4.0. Assays performed on leached soil samples indicated that the effects of sulfuric acid and calcium hydroxide were largely due to $\mathrm{pH}$ rather than to specific ions or osmotic potential. The effect of $\mathrm{pH}$, however, was indirect. Heating the neutral soil to $60^{\circ} \mathrm{C}$ for $2 \mathrm{~h}$ did not alter soil $\mathrm{pH}$ or electrical conductivity but increased fungus activity to levels equivalent to those in acidified soil. We conclude that, in these two soils, heat treatment or low soil $\mathrm{pH}$ suppresses soil organisms that otherwise interfere with growth of Hirsutella rhossiliensis from alginate pellets.

Additional keywords: fungistasis, Heterodera schachtii, plant-parasitic nematodes.
The soil fungus Hirsutella rhossiliensis has been formulated as a potential biocontrol agent against plant-parasitic nematodes (3, 24,31 ), and one of these formulations, consisting of assimilative hyphae embedded and dried in alginate pellets, has performed well in laboratory microcosms (24). The pellets, however, did poorly in field microplots $(16,18)$. Because performance improved if the pellets were added to $60^{\circ} \mathrm{C}$-treated rather than to non-heattreated microplot soil, poor performance was attributed to antagonistic organisms. These putative antagonists of Hirsutella rhossiliensis pellets are not unique to our microplots; poor performance of pellets in non-heat-treated soil and good performance in heat-treated soil was also documented in three commercial tomato fields and in one commercial vineyard (12).

In contrast, pelletized Hirsutella rhossiliensis did well whether the soil was heat treated or not in a second commercial vineyard (12). This was surprising because the two vineyards seemed very similar. Both were mature vineyards near Lodi, CA, and both contained sandy, porous soil with very little organic matter. The soils, however, differed greatly in $\mathrm{pH}$. Soil $\mathrm{pH}$ was nearly neutral where the pellets performed poorly and quite acidic where the pellets performed well. Jaffee (12) inferred that soil $\mathrm{pH}$ might explain why the formulation was more active in one vineyard than in the other.

This inference requires substantiation. First, we are uncertain whether Hirsutella rhossiliensis pellets actually perform better in the acidic than in the neutral soil because experiments at the two vineyards were by necessity independent. Consequently, soil temperature, soil water, pellet quality, and other factors were uncontrolled between sites, and statistical comparisons between vineyards were inappropriate (12). Second, the effect of $\mathrm{pH}$ on Hirsutella rhossiliensis pellets could be direct or could be mediated by other organisms, in particular, organisms antagonistic to Hir-

Corresponding author: B. A. Jaffee; E-mail address: bajaffee@ucdavis.edu

Publication no. P-2001-0122-02R

(C) 2001 The American Phytopathological Society sutella rhossiliensis. Third, $\mathrm{pH}$ may be statistically but not mechanistically associated with causal factors.

In this study, we compared performance of pelletized Hirsutella rhossiliensis in soil from the two vineyards and determined whether soil $\mathrm{pH}$ affected pellet activity. We also attempted to determine whether the effect of $\mathrm{pH}$ was direct or indirect.

\section{MATERIALS AND METHODS}

Fungus pellets and biology. Alginate pellets containing hyphae of Hirsutella rhossiliensis (ATCC 46487) were prepared as described before $(16,24)$. Briefly, thin-walled hyphae rich in assimilated nutrients were grown in shake culture. The hyphae were rinsed free of medium, macerated in $1 \%$ sodium alginate, and pelletized in $\mathrm{CaCl}_{2}$. Pellets were coated with sand (to prevent sticking), dried, and stored in glass vials at $-1^{\circ} \mathrm{C}$ for 1 to 42 days. Pellet mass and diameter were $1.1 \mathrm{mg}$ and $1.9 \mathrm{~mm}$.

When placed in soil, these pellets produce thick-walled "external hyphae" that radiate into the soil and bear phialides. Each phialide bears one conidium. When touched by a passing vermiform nematode, the conidium adheres to the nematode, detaches from the phialide, and within approximately $24 \mathrm{~h}$ penetrates the nematode's cuticle via a germ tube. After the fungus consumes the nematode and converts it into assimilative hyphae, the process repeats as external hyphae, bearing phialides and conidia, grow from the parasitized nematode and into the soil. In vitro at $20^{\circ} \mathrm{C}$, one pellet produces approximately 100,000 conidia in 2 weeks (35). The fungus is specialized for parasitism of nematodes and has little or no competitive saprophytic ability (13).

Soils. The soils were obtained from two mature vineyards, designated site 4 and site 5 as in a previous paper (12). According to the soil survey (29), site 4 contains Tokay fine sandy loam (coarse-loamy mixed, thermic Typic Haploxeroll) and site 5 contains Kingdon fine sandy loam (coarse-loamy mixed, thermic Typic Argixeroll). However, Jaffee (12) found the soils to be loamy sands rather than sandy loams (Table 1). In agreement with the soil survey, soil $\mathrm{pH}$ was nearly neutral at site 4 but acidic at 
site 5 (Table 1). Other characteristics described in Table 1 were determined with standard methods and by the Division of Agriculture and Natural Resources Laboratory (University of California, Davis).

Soil was collected from the 5 to $20 \mathrm{~cm}$ depth adjacent to vines. Site 4 soil contained the root-knot nematode, Meloidogyne spp., and the ring nematode, Criconemella xenoplax. Site 5 soil contained Meloidogyne spp. and the dagger nematode, Xiphinema index. Neither soil contained the cyst nematode, Heterodera schachtii. Because antagonists of Hirsutella rhossiliensis might decline with storage, soil was stored at $10^{\circ} \mathrm{C}$ (except as noted) and used within 14 days of collection.

To remove putative antagonists for some experiments, soil was placed in a glass 500-ml beaker, sealed with aluminum foil, and placed in an oven at $65^{\circ} \mathrm{C}$. When the center of the soil mass increased to $60^{\circ} \mathrm{C}$, the oven temperature was reduced to $60^{\circ} \mathrm{C}$. After $2 \mathrm{~h}$ at $60^{\circ} \mathrm{C}$, the soil was removed from the oven. Cooled soil was placed in an open plastic bag on the laboratory bench. After 4 to $6 \mathrm{~h}$ (to allow potentially toxic volatiles to escape), the soil was mixed, sealed in the plastic bag, and maintained at $22^{\circ} \mathrm{C}$ (to allow the surviving organisms to recolonize). After 2 to 7 days, soil water content was adjusted and the soil was used for experiments.

Vial bioassay for Hirsutella rhossiliensis activity. The following bioassay was used for all experiments. After soil was treated and soil water was adjusted, $1.5 \mathrm{~cm}^{3}$ of soil was placed in a $25-\mathrm{ml}$ plastic vial, and one pellet was placed centrally on the surface of the soil. Additional soil was added and tamped so the pellet was $3 \mathrm{~mm}$ from the bottom of a soil column (height $3.5 \mathrm{~cm}$, diameter $2.5 \mathrm{~cm}$, volume $17 \mathrm{~cm}^{3}$; soil dry mass $24.0 \mathrm{~g}$ ). Preliminary experiments indicated that this positioning of the pellet usually resulted in less than $50 \%$ of the assay nematodes acquiring conidia and thereby increased the ability of the assay to detect treatment differences. Detecting treatment differences becomes difficult when more than $50 \%$ of the assay nematodes acquire conidia, because the relationship between percentage of acquisition and fungus density is nonlinear (it saturates) when the percentage exceeds $50 \%$ (35). Saturation often occurs when the pellet is placed closer to the soil surface, where assay nematodes are added. Each vial was sealed with a plastic lid (the lid had a 2-mmdiameter hole for gas exchange) and placed in a moisture chamber.

After 14 days in the dark at $20^{\circ} \mathrm{C}, 500$ assay nematodes (second-stage juveniles [J2] of Heterodera schachtii) in $0.25 \mathrm{ml}$ of $4 \mathrm{mM} \mathrm{KCl}$ were added to the surface of the soil in each vial. The vials were sealed and returned to $20^{\circ} \mathrm{C}$. After 2 days, nematodes were extracted by wet sieving and sucrose centrifugation (22). The nematode suspension from each vial was adjusted to $10 \mathrm{ml}$, and $2 \mathrm{ml}$ (containing approximately 50 assay nematodes) was examined at $70 \times$ magnification with a dissecting microscope. The number of assay nematodes with at least one adhering conidium of Hirsutella rhossiliensis was determined. In some experiments, other nematodes in the sample were identified to trophic group (40).

Heterodera schachtii was used to assay for Hirsutella rhossiliensis because Heterodera schachtii was not naturally present in the soils (if it were, the time spent in the soil and hence the probability of acquiring conidia would be variable and unknown). Moreover, Heterodera schachtii is quite susceptible to Hirsutella rhossiliensis, and large numbers of vigorous and uniform $\mathrm{J} 2 \mathrm{~s}$ are easily obtained. Heterodera schachtii was cultured on sugar beet in the greenhouse. To obtain J2s, cysts were placed on Baermann funnels. The J2s collected after $6 \mathrm{~h}$ were discarded and the funnels drained and covered with plastic to maintain moisture. After $15 \mathrm{~h}$, the funnels were filled with water and $\mathrm{J} 2 \mathrm{~s}$ were collected every $30 \mathrm{~min}$. The $\mathrm{J} 2 \mathrm{~s}$ were stored with aeration at $10^{\circ} \mathrm{C}$ for 4 to $30 \mathrm{~h}$.

Comparison of soils from sites 4 and 5 (experiment 1). We first hypothesized that Hirsutella rhossiliensis would sporulate better in non-heat-treated soil from site 5 than site 4 . We also hypothesized that heat treatment would enhance sporulation in site 4 soil but not in site 5 soil. Soil was collected from both sites on the same day. Half the soil from each site was heated and half was not. Soil water content was adjusted to $11.0 \%$ (grams of water per $100 \mathrm{~g}$ of dry soil), and the vial bioassay was performed.

Experiment 1 was performed three times (trials 1, 2, and 3), and soil for each trial was collected on different dates. Because site 5 soil seemed to compress more than site 4 soil in trials 1 and 2, we determined, in trial 3, whether source of soil, heat treatment of soil, or water content (11.0 versus $9.0 \%$ ) affected bulk density. We reasoned that reducing the water content would reduce the tendency for site 5 soil to compress. The volume of the soil in each vial was determined by measuring the soil column's height and measuring the volume of a similar column of water.

There were 8 (trial 1 and 2) and 10 (trial 3) replicate vials for each combination of soil and soil treatment. Four additional vials of non-heat-treated soil from each site were included for each trial; these vials did not receive pellets and therefore provided information on resident levels of Hirsutella rhossiliensis.

Decreasing the pH of site 4 soil (experiment 2). We hypothesized that reducing the $\mathrm{pH}$ would increase the activity of pelletized Hirsutella rhossiliensis in site 4 soil. Non-heat-treated soil was mixed and divided into four lots. Each lot received 0, 1, 2, or $4 \mathrm{ml}$ of $0.5 \mathrm{M} \mathrm{H}_{2} \mathrm{SO}_{4}$ per $100 \mathrm{~g}$ of soil (dry weight equivalent); the acid was supplemented with distilled water so the total volume added per lot was $4 \mathrm{ml}$. After acid was added, the soil was mixed. Because adding acid not only reduces soil $\mathrm{pH}$ but also increases the salinity of the soil solution (the acid releases cations from the surface of soil particles) (10), we examined the effect of soil leaching. In trials 1 and 2, however, the soil was not leached. It was mixed and adjusted to $9.0 \%$ water content. After 2 weeks at $22^{\circ} \mathrm{C}$, the soil was packed into vials, and the bioassay was performed. At the time of packing, electrical conductivity of a saturated extract (36) was determined with a conductivity bridge and soil $\mathrm{pH}$ was determined with a $\mathrm{pH}$ meter; to measure $\mathrm{pH}$ for this and all other experiments, soil was wetted to a paste with $0.01 \mathrm{M}$ $\mathrm{CaCl}_{2}$ (34).

In trials 3 to 5 of experiment 2, the soil was leached in the field before it was assayed in vials. In trial 3, the soil, after receiving the different levels of acid, was packed into PVC pipe $(5.1-\mathrm{cm}$ diameter and $5.1 \mathrm{~cm}$ long, $103 \mathrm{~cm}^{3}$ of soil per pipe). There were six replicate pipes for each acid level. These were buried with open ends oriented vertically approximately $15 \mathrm{~cm}$ deep in each of six blocks in the vine row of site 4 . After 16 days and $10 \mathrm{~cm}$ of rain (January 2000), the pipes were recovered. According to the Integrated Pest Management Database (University of California,

TABLE 1. Physical and chemical characteristics of untreated soils from two vineyards ${ }^{\mathrm{a}}$

\begin{tabular}{|c|c|c|c|c|c|c|c|c|c|c|c|c|}
\hline \multirow[b]{2}{*}{ Site } & \multicolumn{2}{|c|}{$\mathrm{pH}$} & \multicolumn{5}{|c|}{$\%$} & \multicolumn{2}{|c|}{$\mathrm{cmol} / \mathrm{kg}$} & \multicolumn{3}{|c|}{$\mathrm{mg} / \mathrm{kg}$} \\
\hline & $\left(\mathrm{CaCl}_{2}\right)^{\mathrm{b}}$ & $(\text { Water })^{\mathrm{c}}$ & Organic matter ${ }^{c}$ & Sand $^{c}$ & Silt $^{\mathrm{c}}$ & Clay $^{\mathrm{c}}$ & $\mathrm{N}^{\mathrm{b}}$ & $\mathrm{Ca}^{\mathrm{b}}$ & $\mathrm{Mg}^{\mathrm{b}}$ & $\mathrm{Mn}^{\mathrm{b}}$ & $\mathrm{Al}^{\mathrm{b}}$ & $\mathrm{P}^{\mathrm{b}}$ \\
\hline 4 & 6.5 & 7.0 & 0.4 & 81 & 15 & 4 & 0.037 & 400 & 78 & 4 & nd & 57 \\
\hline 5 & 4.1 & 5.1 & 0.7 & 81 & 15 & 4 & 0.059 & 206 & 17 & 21 & 12 & 138 \\
\hline
\end{tabular}

a $\mathrm{pH}$ of a $0.01 \mathrm{M} \mathrm{CaCl}_{2}$ - saturated or water-saturated soil paste. $\mathrm{Al}$ (extractable), Mn (DTPA extractable), $\mathrm{P}$ (acid-ammonium fluoride extractable), Ca and Mg (exchangeable using $1 \mathrm{M} \mathrm{KCl}$ ), $\mathrm{N}$ indicates total Kjeldahl $\mathrm{N}$, and nd = not detected.

b Soil samples were collected in March 2000.

c Soil samples were collected in 1998, and data were published previously (12). 
Davis), soil temperatures at $15 \mathrm{~cm}$ depth during leaching ranged from 6 to $12^{\circ} \mathrm{C}$; this was true for all trials involving leaching in experiments 2 and 3 . The soil for each treatment in trial 3 was combined. Soil receiving no acid was divided into two lots; one lot was heated to $60^{\circ} \mathrm{C}$ for $2 \mathrm{~h}$ and the other was not heated; the nonacidified soil was heat-treated to determine whether reducing $\mathrm{pH}$ could substitute for heat treatment. Soil water was adjusted to $9.0 \%$. Within 2 weeks of soil recovery from the field, soil $\mathrm{pH}$ and electrical conductivity were measured and the vial bioassay was performed.

Trials 4 and 5 were identical to trial 3 except that soil was leached in fiberglass bags buried in January 2000 between vine rows rather than in rows (to avoid treatment with herbicide). Each bag (approximately $30 \mathrm{~cm}$ long, $20 \mathrm{~cm}$ wide, $2 \mathrm{~cm}$ thick, and with pore openings of approximately $1.3 \times 1.3 \mathrm{~mm}$ ) contained approximately $900 \mathrm{~g}$ of soil. There was one replicate bag per treatment per trial. When bags were recovered (after 57 days for trial 4 and 67 days for trial 5), approximately $28 \mathrm{~cm}$ of rain had fallen on the vineyard. There were 10 replicate vials per treatment in each trial of experiment 2 .

Increasing the pH of site 5 soil (experiment 3). We hypothesized that increasing the $\mathrm{pH}$ of site 5 soil would reduce the activity of pelletized Hirsutella rhossiliensis. The $\mathrm{pH}$ of site 5 soil at $9.0 \%$ water content was increased by adding $\mathrm{Ca}(\mathrm{OH})_{2}(0,16.8,33.2$, $66.8,133.2$, or $200.0 \mathrm{mg} / 100 \mathrm{~g}$ of soil). In trials 1 and 2, the soil was not leached but was incubated at $22^{\circ} \mathrm{C}$ in the laboratory. After 2 weeks, the $\mathrm{pH}$ and electrical conductivity of the soil were determined and the vial bioassay for Hirsutella rhossiliensis activity was conducted. In trials 3 and 4, soil treated with 0 , 100, or $200 \mathrm{mg}$ of $\mathrm{Ca}(\mathrm{OH})_{2}$ per $100 \mathrm{~g}$ of soil was placed in fiberglass bags and buried $15 \mathrm{~cm}$ deep in the vine row of site 5 (January 2000). After 40 days and $25 \mathrm{~cm}$ of rain (trial 3) and 55 days and $28 \mathrm{~cm}$ of rain (trial 4), the bags of soil were recovered. Soil $\mathrm{pH}$ and electrical conductivity were measured, and the vial bioassay was performed. There were 10 replicate vials per treatment in each trial of experiment 3 .

Statistical analyses. The SAS general linear models procedure (release 7.00, SAS Institute, Cary, NC) was used throughout. The dependent variable for all experiments was the percentage of assay nematodes with Hirsutella rhossiliensis conidia; percentages were arc sine transformed before analyses except for regressions. For experiment 1, we first determined whether the percentage of assay nematodes with conidia differed in non-heat-treated soil from site 4 versus site 5 . We then performed a factorial analysis to detect statistical interactions between source of soil and heat treatment (trials 1 and 2) and between source of soil, heat treat- ment, and water content (trial 3). For experiments 2 and 3, linear regression was performed, with soil $\mathrm{pH}$ or electrical conductivity as the independent variable. Significance was determined at $P \leq 0.05$.

\section{RESULTS}

Comparison of soils from sites 4 and 5 (experiment 1). Although the effect of trial was significant, all trials of experiment 1 exhibited the same pattern. In non-heat-treated soil, the percentage of assay nematodes with conidia was always less in site 4 than in site 5 soil (Fig. 1). Whereas heat treatment always increased fungus activity in site 4 soil, it had no effect on activity (Fig. 1A) or decreased activity (Fig. 1B through D) in site 5 soil. Thus, the statistical interaction of heat treatment and soil source was significant.

When soil water was $11.0 \%$ in trial 3 , bulk density (gram of dry soil per cubic centimeter of soil, mean \pm SE) was greater with site 5 soil than with site 4 soil $(1.46 \pm 0.01$ versus $1.41 \pm 0.01)$; greater in heat-treated than in non-heat-treated site 5 soil $(1.48 \pm 0.01$ versus $1.44 \pm 0.01)$; and similar in heat-treated and non-heattreated site 4 soil $(1.42 \pm 0.01$ versus $1.41 \pm 0.01)$. When soil water content was $9.0 \%$ however, bulk density was $1.40 \pm 0.01$, regardless of soil source or heat treatment. To attain uniform bulk densities, the water content in experiments 2 and 3 was $9.0 \%$.

To determine whether heat treatment changed soil $\mathrm{pH}, \mathrm{pH}$ of non-heat-treated and heat-treated soil was measured before soil was packed into vials in trials 2 and 3 . The $\mathrm{pH}$ of site 4 soil was 6.5 in trial 2 and 6.4 in trial 3, regardless of heat treatment. The $\mathrm{pH}$ of site 5 soil was 4.5 in trial 2 and 4.6 in trial 3, regardless of heat treatment.

In vials receiving no pellets, 0 and $<1 \%$ of the assay nematodes had adhering conidia in site 4 and site 5 soil, respectively (data not shown). Thus, resident Hirsutella rhossiliensis was not present or was present in very small numbers.

Decreasing the pH of site 4 soil (experiment 2). Addition of acid reduced the $\mathrm{pH}$ of site 4 soil (Fig. 2A). The data were similar among trials, but the $\mathrm{pH}$ reduction was less in leached soil than in nonleached soil. Soil $\mathrm{pH}$ increased with greater leaching time (trial $5>4>3$ ). Heat treatment did not affect the $\mathrm{pH}$ of the nonacidified soils that were leached (Fig. 2A).

Electrical conductivity and therefore salt concentration increased substantially with the addition of acid (Fig. 2B). Leaching removed much of the salt from soils treated with the highest acid rate and removed nearly all of the salt from soils treated with lower acid rates. Heat treatment did not affect the electrical conductivity of the nonacidified soils that were leached (Fig. 2B). trial 1 (11\% soil water)
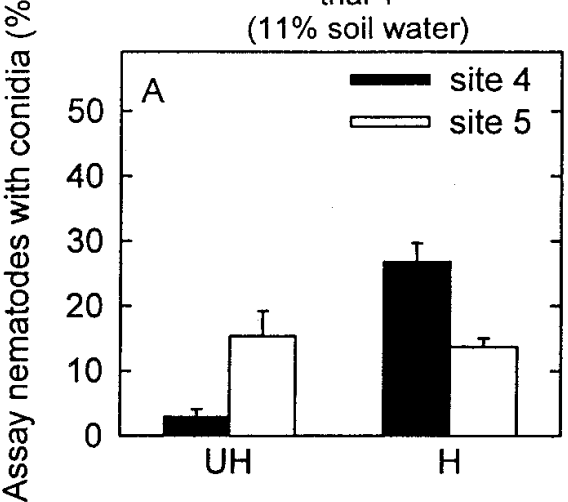

trial 2

( $11 \%$ soil water)
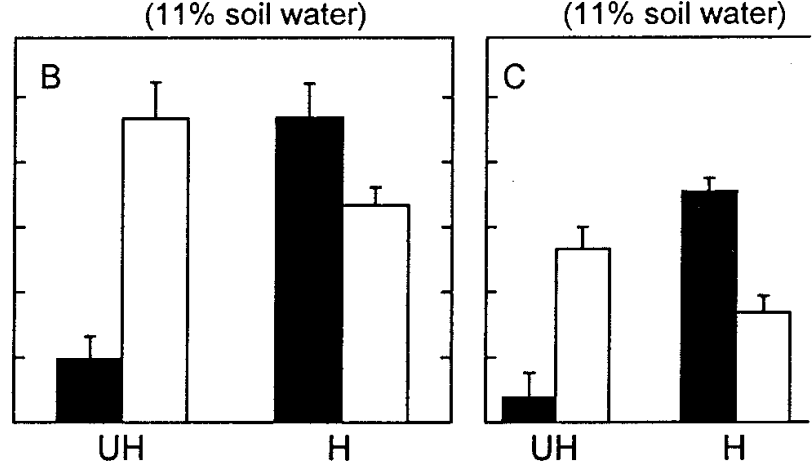

trial 3

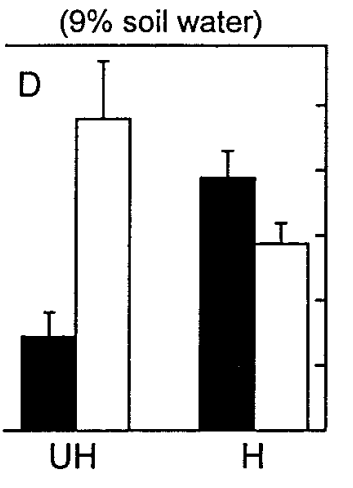

Nonheat-treated $(\mathrm{UH})$ or heat-treated $(\mathrm{H})$ soil

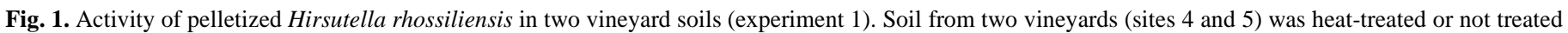

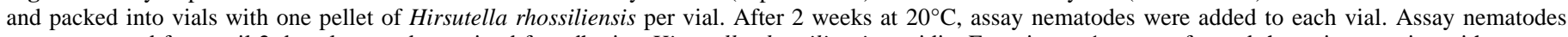

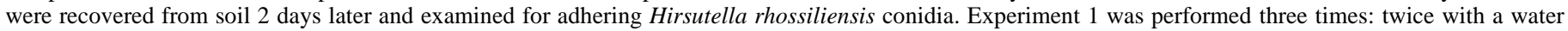
content of $11 \%$ (trials 1 and 2) and once with water contents of 9 and 11\% (trial 3). Each value is the mean (+SE) of 8 (trials 1 and 2 ) or 10 (trial 3 ) replicate vials. 
In nonheated and nonacidified soil from site 4 , the percentage of assay nematodes with adherent conidia was near zero in four of five trials (Fig. 2C). Heating of the nonacidified soil greatly increased the percentage of assay nematodes with conidia (Fig. 2C). Addition of intermediate levels of acid to non-heat-treated soil also increased the percentage of assay nematodes with conidia (Fig. 2C). The percentage of assay nematodes with conidia was less in soil receiving $2 \mathrm{ml}$ of acid than in the heated controls, but the differences were relatively small and were not statistically significant (in an analysis across all three trials, $P=0.16$ ).

In the leached site 4 soil, numbers of bacterivorous nematodes decreased as soil $\mathrm{pH}$ decreased (mean numbers recovered per vial were $100,82,31$, and 20 at $\mathrm{pH} 6.6,5.3,4.5$, and 3.7, respectively); numbers of nematodes in other trophic groups were small (usually <10 per vial) regardless of treatment (data not shown). In nonleached site 4 soil, resident nematode numbers were small (usually $<10$ of any trophic group per vial) regardless of treatment (data not shown). Enchytraeids were rarely observed.

Increasing the $\mathbf{p H}$ of site 5 soil (experiment 3). Addition of $\mathrm{Ca}(\mathrm{OH})_{2}$ increased the $\mathrm{pH}$ of site 5 soil (Fig. 3A). The increase was moderated by leaching (Fig. 3A). Nontreated, nonleached soil from site 5 was saltier than nontreated, nonleached soil from site 4 (Fig. $3 \mathrm{~B}$ versus Fig. 2B). Electrical conductivity increased slightly with addition of $\mathrm{Ca}(\mathrm{OH})_{2}$ and was greatly reduced by leaching (Fig. 3B). site 4
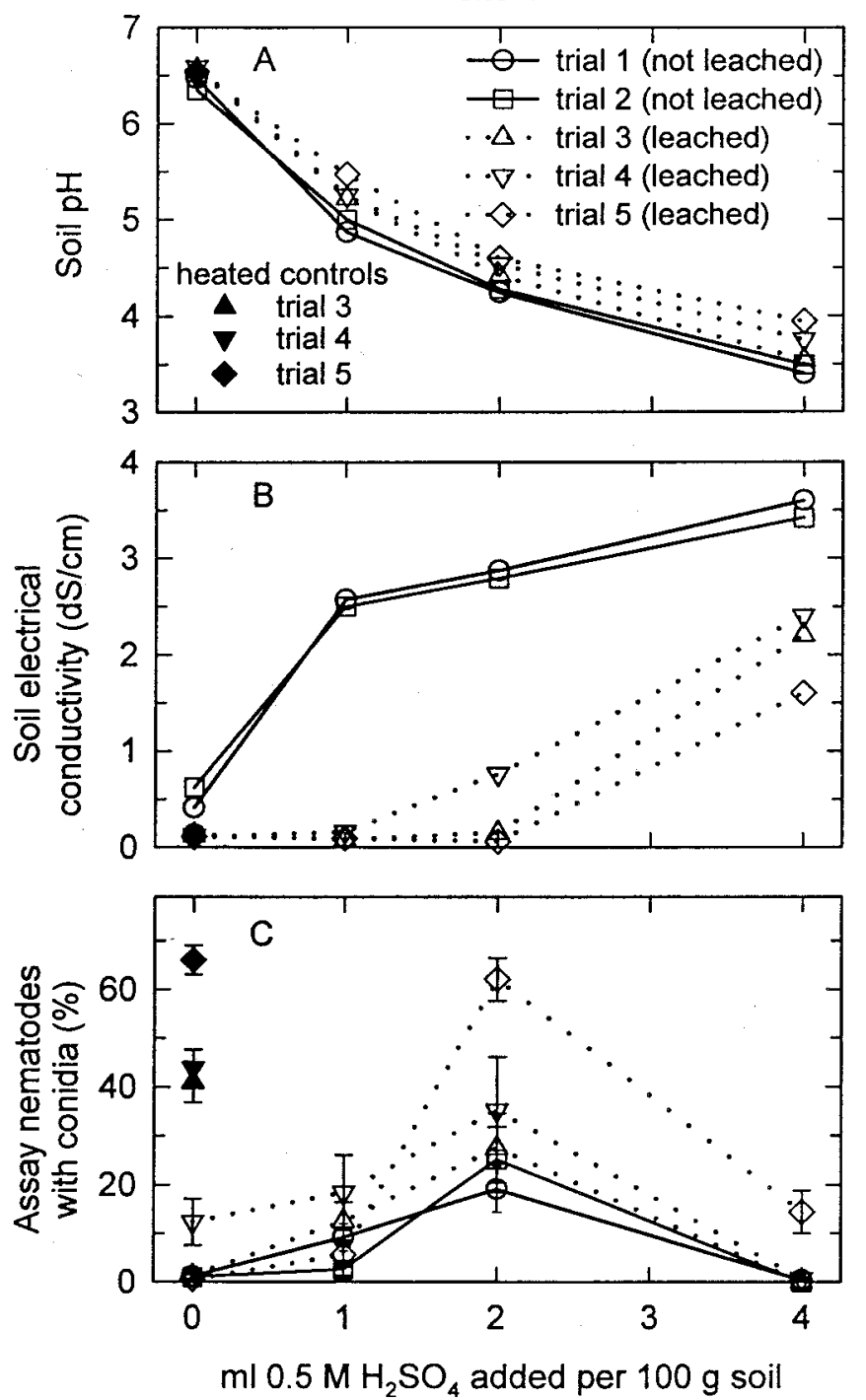

Fig. 2. Effect of sulfuric acid on soil $\mathrm{pH}$, soil electrical conductivity, and activity of pelletized Hirsutella rhossiliensis in site 4 soil (experiment 2). Non-heat-treated soil from site 4 was treated with sulfuric acid and was either not leached (trials 1 and 2) or leached (trials 3 to 5). After leaching, half of the soil receiving no acid was heated to $60^{\circ} \mathrm{C}$ for $2 \mathrm{~h}$; no other soil was heattreated. A, Soil pH. Before the soils were assayed for fungus activity, subsamples were moistened to a saturated paste with $0.01 \mathrm{M} \mathrm{CaCl}_{2}$, and $\mathrm{pH}$ was determined. B, Soil solutes. Before the soils were assayed for fungus activity, the electrical conductivity (deciSiemens per centimeter) of a saturated extract was determined. C, Fungus activity. The soils were adjusted to $9 \%$ soil water content and packed into vials with one pellet of Hirsutella rhossiliensis per vial. After 2 weeks at $20^{\circ} \mathrm{C}$, assay nematodes were added to each vial. Assay nematodes were recovered from soil 2 days later and examined for adhering Hirsutella rhossiliensis conidia. Each value for $\mathrm{pH}$ and electrical conductivity represents one determination. Each value for fungus activity is the mean $( \pm \mathrm{SE})$ of 10 replicate vials.
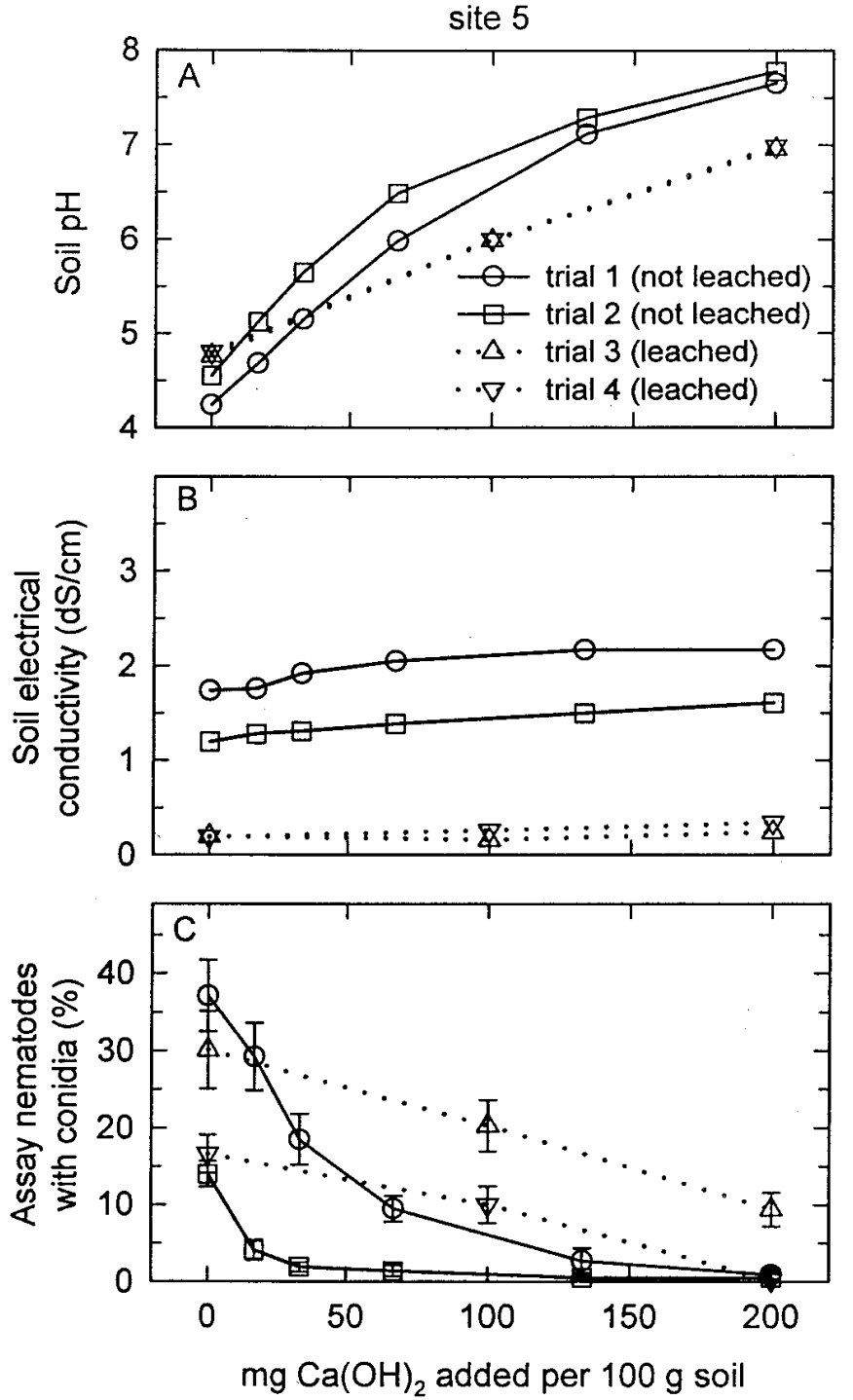

Fig. 3. Effect of calcium hydroxide on soil $\mathrm{pH}$, soil electrical conductivity, and activity of pelletized Hirsutella rhossiliensis in site 5 soil (experiment 3 ). Non-heat-treated soil from site 5 was treated with calcium hydroxide and either not leached (trials 1 and 2) or leached (trials 3 and 4). A, Soil pH. Before the soils were assayed for fungus activity, subsamples were moistened to a saturated paste with $0.01 \mathrm{M} \mathrm{CaCl}_{2}$, and $\mathrm{pH}$ was determined. B, Soil solutes. Before the soils were assayed for fungus activity, the electrical conductivity (deciSiemens per centimeter) of a saturated extract was determined. C, Fungus activity. The soils were adjusted to $9 \%$ soil water content and packed into vials with one pellet of Hirsutella rhossiliensis per vial. After 2 weeks at $20^{\circ} \mathrm{C}$, assay nematodes were added to each vial. Assay nematodes were recovered from soil 2 days later and examined for adhering Hirsutella rhossiliensis conidia. Each value for $\mathrm{pH}$ and electrical conductivity represents one determination. Each value for fungus activity is the mean $( \pm \mathrm{SE})$ of 10 replicate vials. 
Addition of $\mathrm{Ca}(\mathrm{OH})_{2}$ reduced the percentage of assay nematodes with conidia, but the reduction was exponential in nonleached soil whereas it was linear and less dramatic in leached soil (Fig. 3C). One lot of soil was used to start trials 1 and 3, and a second lot was used for trials 2 and 4; the percentage of assay nematodes with conidia was greater with the first lot of soil than with the second. Regardless of treatment, resident nematode numbers were small (usually $<10$ of any trophic group per vial) in site 5 soil (data not shown). Enchytraeids were rarely observed.

Relationship between fungus activity and soil pH or electrical activity. If data from all trials of experiments 2 and 3 were combined (excluding data from heat-treated controls), the percentage of assay nematodes with conidia was related to soil $\mathrm{pH}$ in site 4 soil (Fig. 4A). The percentage increased as $\mathrm{pH}$ decreased from 6.5 to approximately 4.2 and decreased at lower $\mathrm{pH}$ values. At $\mathrm{pH}$ values $>4.2$, the regression of percentage of nematodes with conidia on soil $\mathrm{pH}$ was significant $\left(P<0.01, r^{2}=0.42\right)$ in site 4 soil.

In site 5 soil, the percentage was greatest in nontreated soil $(\mathrm{pH}$ approximately 4.5) and decreased as the $\mathrm{pH}$ increased (Fig. 4B); the regression of percentage of nematodes with conidia on soil $\mathrm{pH}$ was significant $\left(P<0.01, r^{2}=0.61\right)$. Thus, the pattern was similar at both sites (activity was low when $\mathrm{pH}$ values were near 6.5 and activity was substantial when $\mathrm{pH}$ values were near 4.5).

In contrast, there was no clear relationship between electrical conductivity of the soil solution and fungus activity (Fig. 4C and D); regressions of fungus activity on electrical conductivity were insignificant at both sites.

\section{DISCUSSION}

As hypothesized, the activity of pelletized Hirsutella rhossiliensis substantially increased when a nearly neutral vineyard soil was acidified. Similarly, the activity substantially decreased when an acidic vineyard soil was limed. In both soils, activity was greatest when the $\mathrm{pH}_{\text {calcium chloride }}$ was approximately 4.5 (the normal pH for the acidic soil) and was minimal at $\mathrm{pH} 6.5$ (the normal $\mathrm{pH}$ for the neutral soil). It follows that soil $\mathrm{pH}$ underlies much of the difference in how pelletized Hirsutella rhossiliensis performed in the two vineyards (12).

Although $\mathrm{pH}$ may directly affect the fungus, the current data point toward an indirect influence. Heating the neutral soil to $60^{\circ} \mathrm{C}$ for $2 \mathrm{~h}$ did not alter soil $\mathrm{pH}$ or soil electrical conductivity. It is also doubtful that such gentle heating greatly changed other chemical or physical properties. But heat treatment substantially suppresses soil organisms (19) and substantially increased pellet activity in the neutral soil. We infer that both heating and low $\mathrm{pH}$ suppress organisms that somehow interfere with Hirsutella rhossiliensis pellets. In at least three commercial tomato fields and in the neutral vineyard of this study, these unknown organisms are smaller than $20 \mu \mathrm{m}$; exclusion of larger organisms did not improve pellet activity (12).

Our inference that heat treatment suppressed antagonists is consistent with the principles that soil is biologically buffered against introduced organisms $(4,7,39)$ and that introducing nematophagous and other fungi is therefore easier if the soil community has been simplified $(6,8,27,28,32)$. But the effect of heat treatment on pellet performance might be explained by other processes. Perhaps heating alleviated fungistasis by releasing nutrients required by the fungus or by suppressing organisms inducing dormancy $(25,26)$. An explanation based on fungistasis, however, is inconsistent with the following observations: Hirsutella rhossiliensis pellets are nutrient-independent, i.e., hyphae grow from pellets and produce abundant conidia even when pellets are placed in plastic moisture chambers without exogenous nutrients (35); un-
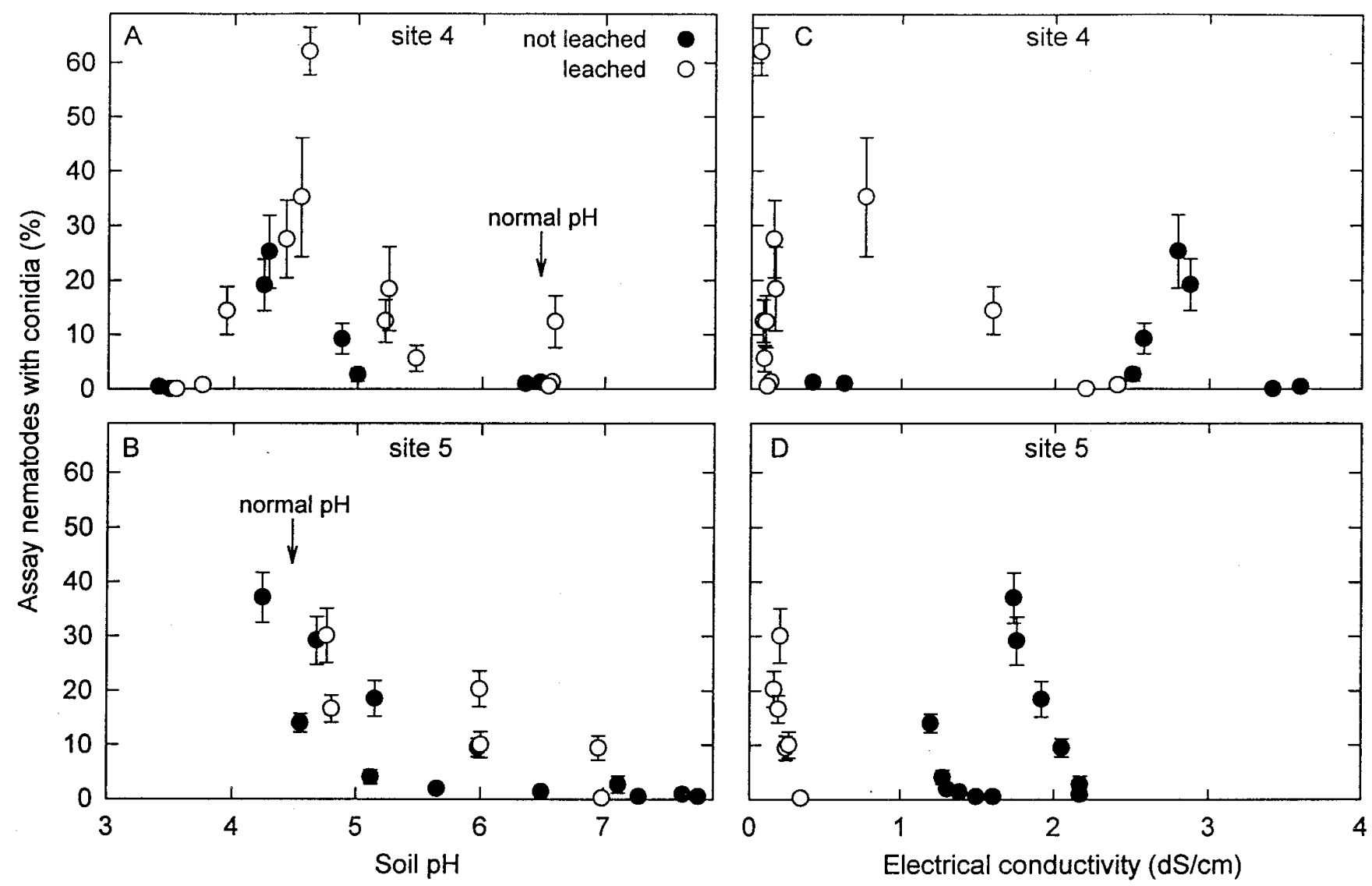

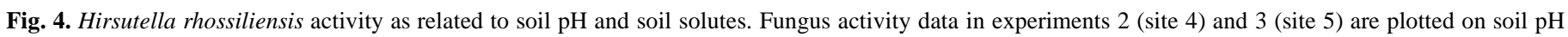
and on electrical conductivity (deciSiemens per centimeter). Data from heat-treated soil are excluded. Each value is the mean ( \pm SE) of 10 replicate vials. 
like fungistasis-sensitive propagules, pelletized hyphae did not remain dormant in non-heat-treated soil (B. A. Jaffee and R. J. Zasoski, unpublished data); and most importantly, sensitivity to fungistasis should confer an ecological advantage (4), but Hirsutella rhossiliensis hyphae gain no advantage by remaining dormant in nonheated, nematode-infested soil.

Although heat treatment improved pellet performance in the neutral soil, it somewhat reduced activity in the acidic soil. If this reduction is real (the statistics were inconclusive), perhaps heating of the acidic soil solubilized some inhibitory component (23). This possibility is somewhat bothersome because it undermines our notion of "gentle heating".

The effect of $\mathrm{pH}$ might have been anticipated. First, nematodeendoparasitic and nematode-trapping fungi were detected more frequently in acidic than in neutral soils of Ireland (9); Hirsutella rhossiliensis, however, was not reported. Second, the optimum $\mathrm{pH}$ for Hirsutella rhossiliensis sporulation from parasitized nematodes in vitro was approximately 5.3 (21); these in vitro data show that a direct effect of $\mathrm{pH}$ cannot be completely discounted. Finally, among 10 peach and almond orchards surveyed in 1986, the one with the largest resident population of Hirsutella rhossiliensis (B. A. Jaffee, unpublished data) was very acidic; the $\mathrm{pH}$ of this soil, which was designated "soil M", was $4.4(14,15)$. Soil M became the standard soil used by Jaffee and colleagues to study Hirsutella rhossiliensis.

The current data on $\mathrm{pH}$ help explain why Hirsutella rhossiliensis pellets performed much better in laboratory microcosms (24) than in campus microplots $(16,18)$. Although loamy sands were used in both types of studies, soil $\mathrm{pH}$ was 4.4 in the laboratory (soil $\mathrm{M}$ was used) and 7.3 in the microplots.

The negative effect of $\mathrm{pH}$ in the microplots, as in the neutral vineyard, was largely indirect; gentle heating of microplot soil greatly improved pellet performance $(16,18)$. The situation in the microplots, however, differed from that in the neutral vineyard and in three commercial tomato fields (12) because the microplots contained large numbers of enchytraeid worms (Oligochaeta) that are highly motile and consume Hirsutella rhossiliensis pellets (17). Consequently, pellet activity in the microplots was not greatly improved unless the soil was both heated and surrounded by mesh to prevent re-invasion by enchytraeids (19). Given the high soil $\mathrm{pH}$ and large numbers of enchytraeids, pelletized Hirsutella rhossiliensis had no chance to control plant-parasitic nematodes in the campus microplots.

Many others have found that soil $\mathrm{pH}$ affects biological control of soil pests (4). For example, giant vampyrellid amoebae perforated more fungal spores in neutral soils than in acidic soils (11). More recently, receptivity of soil to three root pathogens was correlated with soil $\mathrm{pH}$ (30); and although various soil chemical and physical factors were statistically significant, biological factors seemed most important because receptivity was greatly increased by sterilization of soil with gamma radiation.

We did not directly assess fungal growth and activity. Instead, we used a bioassay in which target nematodes were added to soil, recovered, and examined for attack by the control agent. Although the bioassay directly relates to biological control, it depends not only on conidial numbers but also on nematode movement through soil (35). If our treatments affected such movement, it would be incorrect to measure fungus activity by quantifying the percentage of assay nematodes with conidia. But most studies indicate a minimal direct effect of soil $\mathrm{pH}$ on nematodes (38). Moreover, heat treatment greatly increased the percentage of assay nematodes with conidia, and there is no basis for inferring that heat treatment increases nematode movement or susceptibility.

Specific ions, on the other hand, may attract or repel nematodes $(1,2,33)$ and thereby affect the number of nematodes encountering conidia. Similarly, specific ions and osmotic potential may enhance or suppress Hirsutella rhossiliensis (5,20,21). Although osmotic or specific ion effects were indicated in the study (pellet activity was greater in leached soil than in nonleached soil), these effects were clearly minor relative to those of $\mathrm{pH}$.

Two other laboratories have reported greater success than ours in adding Hirsutella rhossiliensis to soil $(3,31)$. It is unclear whether the success reflects differences in formulation quality, formulation quantity, soil, fungal isolate, or experimental procedure. Another formulation, consisting of vegetative hyphae of the same isolate used in this study, performed equally well in autoclaved or nonautoclaved organic soil; significantly, the soil $\mathrm{pH}$ was 4.7 (37).

We now better understand why pelletized Hirsutella rhossiliensis failed to control plant-parasitic nematodes in our campus microplots and why fungus activity was greater in one vineyard than in another. Applying this information, however, is not easy. We might suggest that the pellets be studied and tested only in acidic soils, but such soils are relatively rare in agriculture. Moreover, strongly acidic soils often are amended to raise $\mathrm{pH}$, and the benefits from increased $\mathrm{pH}$ could outweigh those from nematode control. Instead, it may be useful to modify the formulation, thereby reducing antagonism by other organisms. A previous study using the neutral vineyard soil showed that inoculum consisting of Hirsutella rhossiliensis-parasitized nematodes rather than pellets performed well in bioassays whether the soil was heated or not (13). We again suggest that the pellet might perform better if it more accurately mimicked the fungus-parasitized nematode. A protective covering, like the nematode's cuticle, could be especially valuable.

\section{ACKNOWLEDGMENTS}

We thank S. Lange and J. Tecklenburg for allowing us to work in their vineyards, E. Caswell-Chen for suggestions, L. Epstein and T. Gordon for comments on a draft of the manuscript, and K. Johansen for technical help.

\section{LITERATURE CITED}

1. Abou-Setta, M. M., and Duncan, L. W. 1998. Attraction of Tylenchulus semipenetrans and Meloidogyne javanica to salts in vitro. Nematropica 28:49-59.

2. Castro, C. E., Belser, N. O., McKinney, H. E., and Thomason, I. J. 1990. Strong repellancy of the root knot nematode, Meloidogyne incognita, by specific inorganic ions. J. Chem. Ecol. 16:1199-1205.

3. Chen, S. Y., Chen, F. J., Liu, X. Z., and Reese, C. D. 1999. Investigation of fungal antagonists of Heterodera glycines in Minnesota. (Abstr.) J. Nematol. 31:527.

4. Cook, R. J., and Baker, K. F. 1983. The Nature and Practice of Biological Control of Plant Pathogens. The American Phytopathological Society, St. Paul, MN.

5. Eayre, C. G., Jaffee, B. A., and Zehr, E. I. 1990. Influence of potassium upon germination in the nematophagous fungus, Hirsutella rhossiliensis. J. Nematol. 22:612-613.

6. Eren, J., and Pramer, D. 1978. Growth and activity of the nematodetrapping fungus Arthrobotrys conoides in soil. Pages 121-127 in: Microbial Ecology. M. W. Loutit and J. A. R. Miles, eds. Springer-Verlag, Berlin.

7. Garrett, S. D. 1956. Biology of Root-Infecting Fungi. Cambridge University Press, New York.

8. Giuma, A. Y., and Cooke, R. C. 1974. Potential of Nematoctonus conidia for biological control of soil-borne phytonematodes. Soil Biol. Biochem. 6:217-220.

9. Gray, N. F. 1985. Ecology of nematophagous fungi: Effect of soil moisture, organic matter, $\mathrm{pH}$, and nematode density on distribution. Soil Biol. Biochem. 17:449-507.

10. Hågvar, S., and Abrahamsen, G. 1980. Colonization by enchytraeidae, collembola and acari in sterile soil samples with adjusted $\mathrm{pH}$ levels. Oikos 34:245-258.

11. Homma, Y., and Cook, R. J. 1985. Influence of matric and osmotic potentials and soil $\mathrm{pH}$ on the activity of giant vampyrellid amoebae. Phytopathology 75:243-246.

12. Jaffee, B. A. 1999. Enchytraeids and nematophagous fungi in tomato fields and vineyards. Phytopathology 89:398-406.

13. Jaffee, B. A. 2000. Augmentation of soil with the nematophagous fungi Hirsutella rhossiliensis and Arthrobotrys haptotyla. Phytopathology 
90:498-504.

14. Jaffee, B. A., Gaspard, J. T., and Ferris, H. 1989. Density-dependent parasitism of the soil-borne nematode Criconemella xenoplax by the nematophagous fungus Hirsutella rhossiliensis. Microb. Ecol. 17:193200 .

15. Jaffee, B. A., Gaspard, J. T., Ferris, H., and Muldoon, A. E. 1988. Quantification of parasitism of the soil-borne nematode Criconemella xenoplax by the nematophagous fungus Hirsutella rhossiliensis. Soil Biol. Biochem. 20:631-636.

16. Jaffee, B. A., and Muldoon, A. E. 1997. Suppression of the root-knot nematode Meloidogyne javanica by alginate pellets containing the nematophagous fungi Hirsutella rhossiliensis, Monacrosporium cionopagum and M. ellipsosporum. Biocontrol Sci. Technol. 7:203-217.

17. Jaffee, B. A., Muldoon, A. E., and Didden, W. A. M. 1997. Enchytraeids and nematophagous fungi in soil microcosms. Biol. Fertil. Soils 25:382388.

18. Jaffee, B. A., Muldoon, A. E., and Westerdahl, B. B. 1996. Failure of a mycelial formulation of the nematophagous fungus Hirsutella rhossiliensis to suppress the nematode Heterodera schachtii. Biol. Control 6:340-346.

19. Jaffee, B. A., Santos, P. F., and Muldoon, A. E. 1997. Suppression of nematophagous fungi by enchytraeid worms: A field exclosure experiment. Oecologia 112:412-423.

20. Jaffee, B. A., and Zehr, E. I. 1983. Effects of certain ions, osmotic potential, and soil solutions on parasitism of Criconemella xenoplax by Hirsutella rhossiliensis. Phytopathology 73:544-546.

21. Jaffee, B. A., and Zehr, E. I. 1983. Sporulation of the fungus Hirsutella rhossiliensis from the nematode Criconemella xenoplax. Plant Dis. 67:1265-1267.

22. Jenkins, W. R. 1964. A rapid centrifugal-flotation technique for separating nematodes from soil. Plant Dis. Rep. 48:692.

23. Ko, W. H., and Hora, F. K. 1971. Fungitoxicity in certain Hawaiian soils. Soil Sci. 112:276-279.

24. Lackey, B. A., Muldoon, A. E., and Jaffee, B. A. 1993. Alginate pellet formulation of Hirsutella rhossiliensis for biological control of plantparasitic nematodes. Biol. Control 3:155-160.

25. Liebman, J. A., and Epstein, L. 1992. Activity of fungistatic compounds from soil. Phytopathology 82:147-153.

26. Lockwood, J. L. 1988. Evolution of concepts associated with soilborne plant pathogens. Annu. Rev. Phytopathol. 26:93-121.

27. Mankau, R. 1962. Soil fungistasis and nematophagous fungi. Phytopathology 52:611-615.
28. Marois, J. J., and Mitchell, D. J. 1981. Effects of fungal communities on the pathogenic and saprophytic activities of Fusarium oxysporum f. sp. radicis-lycospersici. Phytopathology 71:1251-1256.

29. McElhiney, M. A. 1992. Soil Survey of San Joaquin County, California. USDA Soil Conservation Service, National Cooperative Soil Survey, California Department of Conservation.

30. Oyarzun, P. J., Gerlagh, M., and Zadoks, J. C. 1998. Factors associated with soil receptivity to some fungal root rot pathogens of peas. Appl. Soil Ecol. 10:151-169.

31. Patel, A. V., Rose, T., Gutberlet, V., Muller, J., and Vorlop, K. D. 1999. Controlled release of Hirsutella rhossiliensis from hollow beads for biological control of plant-parasitic nematodes. (Abstr.) J. Nematol. 31:562.

32. Pereira, R. M., Alves, S. B., and Stimac, J. L. 1993. Growth of Beauveria bassiana in fire ant nest soil with amendments. J. Invertebr. Pathol. 62:9-14.

33. Robinson, A. F., and Jaffee, B. A. 1996. Repulsion of Meloidogyne incognita by alginate pellets containing hyphae of Monacrosporium cionopagum, M. ellipsosporum, or Hirsutella rhossiliensis. J. Nematol. 28:133-147.

34. Smiley, R. W., and Cook, R. J. 1972. Use and abuse of the soil pH measurement. Phytopathology 62:193-194.

35. Tedford, E. C., Jaffee, B. A., and Muldoon, A. E. 1995. Suppression of the nematode Heterodera schachtii by the fungus Hirsutella rhossiliensis as affected by fungus population density and nematode movement. Phytopathology 85:613-617.

36. U.S. Salinity Laboratory Staff. 1954. Diagnosis and Improvement of Saline and Alkaline soils. L. A. Richards, ed. U.S. Dep. Agric. Handb. 60.

37. Viaene, N. M., and Abawi, G. S. 2000. Hirsutella rhossiliensis and Verticillium chlamydosporium as biocontrol agents of the root-knot nematode Meloidogyne hapla on lettuce. J. Nematol. 32:85-100.

38. Wallace, H. R. 1971. Abiotic influences in the soil environment. Pages 257-280 in: Plant-Parasitic Nematodes. Vol. 1. B. M. Zuckerman, W. F. Mai, and R. A. Rohde, eds. Academic Press, New York.

39. Wilhelm, S. 1965. Analysis of biological balance in natural soil. Pages 509-518 in: Ecology of Soil-Borne Plant Pathogens-Prelude to Biological Control. K. F. Baker and W. C. Snyder, eds. University of California Press, Berkeley.

40. Yeates, G. W., Bongers, T., de Goede, R. G. M., Freckman, D. W., and Georgieva, S. S. 1993. Feeding habits in soil nematode families and genera - An outline for soil ecologists. J. Nematol. 25:315-331. 